\title{
The last racially separated church in the Dutch Reformed family of churches: Constituting the Synod of the Evangelical Reformed Church in Africa
}

\begin{abstract}
The author describes the history and circumstances around the founding of the last racially separated "daughter" church of the white Dutch Reformed Church (DRC), the Evangelical Reformed Church in Africa (ERCA) in Namibia in 1975. He places this in the context of racial and ethnic church formation by the DRC subsequent to the publication of the Tomlinson Report. The DRC in Namibia needed a black partner church in the north of Namibia in order to counter the alliance between Swapo and the Evangelical Lutheran Church of Ovambo-Kavango. ERCA was miniscule in size in comparison to the Lutheran and Roman Catholic churches in the northern "homelands" of Namibia, which was one reason why indigenous elders as well as some missionaries considered it unwise to institute a separate church at that time. The objections were overruled by the "mother" church (the DRC) that held the upper hand since it funded mission work in the northern "homelands". The author concludes with some critical comments about this episode of DRC mission history.
\end{abstract}

\section{INTRODUCTION}

The institution by the Dutch Reformed Church (DRC) in South Africa of racially separated churches has been thoroughly documented (cf. Smith 1984; Saayman 1979; Saayman 2007). This article is not meant to cover that ground again. It is rather a first attempt to recount the history of constituting the last of these racially separated daughter churches ${ }^{2}$, the Evangelical Reformed Church in Africa (ERCA) ${ }^{3}$. The constituting synod of this church took place from 3 9 July 1975 at the DRC mission station and Theological School at Orumana in Kaokoland, the north-western province of present day Namibia (cf. Strauss 1975). An in-depth analysis of the circumstances around the birth of this new church has not been attempted in an academic article yet, and this is the focus of this article. The only critical analysis of the constituting of the church (Lombard \& Tjingaete 1995) deals more extensively with developments later in its life, especially after the liberation of Namibia in 1990. The authors note serious objections to the formation of a racially separated church in Namibia at the time (:21-23). The article was

1 Prof Willem Saayman is Professor Emeritus in Missiology at Unisa in Pretoria. He served as DRC missionary in Namibia between 1974 and 1978.

2 At the time I am writing about (the 1970s), the term daughter churches was already a contested concept. It was used to describe the younger churches which came into being as the fruit of mission work of the older churches in Western Europe and America, especially during the late $19^{\text {th }}$ and early $20^{\text {th }}$ century. I am going to use the term in this article, as it was the term used in discussions and conversations at the time. I am fully aware of the negative interpretations which can be connected to the term.

3 The Afrikaans acronym, by which the church was widely known, is "EGKA". ERCA consisted at the time of three congregations, one in each of the three big "homelands" in the north of Namibia, namely Kavango, Ovambo and Kaokoland. 
written in 1995, though, twenty years after the constituting of the church. Tjingaete, the main source of information (:21), was not present at or involved in the constituting of the synod, and therefore had no firsthand information about it. Furthermore, the article was written in 1995, in the context of a liberated Namibia, which was very far removed from the 1975 context of SWA in the midst of a vicious liberation war. Still, the objections of the authors must be taken seriously, and the present article is meant to clear up some of the contemporary contextual issues around the constituting of ERCA ${ }^{4}$, which also help to clarify some of the vexing issues of its later life discussed by Lombard and Tjingaete.

\section{HISTORICAL BACKGROUND}

The historical background of DRC mission in South West Africa (present day Namibia) ${ }^{5}$ has been extensively documented by Kritzinger (1972) and Buys and Nambala (2003). In very brief terms, the DRC did not engage in independent mission work in its early years in Namibia (after the First World War, 1914-1918, when the Union of SA was mandated by the League of Nations to administer the previously German colony and large numbers of Afrikaans-speaking South Africans settled there). It rather co-operated with two congenial mission societies already at work there, namely the (Lutheran) Rhenish and Finnish Mission Societies (cf. Buys \& Nambala 2003:361-362). After the Second World War this co-operation was institutionalised in 1947 in the so-called "Driehoek-ooreenkoms" (Triangular Agreement), in terms of which the DRC provided financial and other assistance to the Rhenish and the Fins ${ }^{6}$. In 1955 the DRC (still in consultation with the Finns - Buys \& Nambala 2003:251) started its own mission work in the Kaokoland, where neither of the two Lutheran societies was working at the time. Kaokoland, indigenous home of the Ovahimba/Herero, is a vast expanse of desert and semi-desert country, with a very low population density. The Ovahimba are very tradition-bound, and Christianity made very little inroads in the community - in the 1970s, less than $5 \%$ of the population of around 12,000 were Christianised. The Triangular Agreement fell into dispute in the late 1960s (partly as a result of disagreements about the DRC's support for apartheid, :362), and the DRC started mission work in the late 1960s also in Kavango. The first mission station was situated about $50 \mathrm{~km}$ east of Rundu (the capital of Kavango Province) at Takuasa. Again this was done in consultation with the Finns. This was a very sensitive area, as Kavango was more or less divided in half between Roman Catholics (east of Rundu), and Protestants (Evangelical Lutherans, west of Rundu). So Takuasa was situated at the extreme east of Protestant influence in Kavango, mainly because the Lutheran Finnish Mission Society was not working so far east of Rundu ${ }^{7}$. Still, by the early 1970s, Takuasa congregation, with more than 500 confessing members, was the biggest DRC mission

4 The author was at the time Lecturer at the Orumana Theological Scool in Kaokoland, having served as missionary minister of the congregation in Kavango before. He was elected moderator of ERCA at the first synod, and therefore writes as participant observer.

5 It is important to keep in mind that historical developments in SWA itself, as well as developments in SA, have to be taken very seriouslu when analysing and evaluating DRC mission in SWA. This is so because it was difficult to characterise "Suidwes" (as it was referred to in colloquial Afrikaans) as either "foreign mission" or "home mission" in DRC terms. Theoretically this was a German colony placed under SA administration by the League of Nations after World War 1, but practically it was regarded as nearly a "fifth province", first of the Union, and then later the Republic of SA. I return to this reality later on.

6 Buys \& Nambala (2003:362) provide a very reliable brief synopsis of the content and aims of this agreement.

7 In the early 1970s ELOK and the DRC mission at Takuasa joined forces, for example in youth work in the Secondary Schools east of Rundu. 
congregation in the three northern "homelands" 8 . As the Ovahimba people were nomadic migrants, the numbers of the Orumano congregation are even more difficult to determine - but it was certainly lower than those in the Kavango. DRC mission work in Ovambo was initiated only in 1973 near Onuno, close to the border of Angola, by Rev Paulus (on his own initiative, without any consultation with the DRC, :252), who had previously worked in Kavango.

The first incursion by armed insurgents belonging to Swapo (the South West African People's Organisation, then a liberation movement, since 1990 the governing party of independent Namibia), took place in the north of Ovambo in 1966. From that time onwards relationships between the DRC and the Rhenish and Finnish mission societies, as well as the resulting autonomous churches, the Rhenish Evangelical Lutheran Church in SWA (ELCSWA) in the south, and the Finnish Evangelical Lutheran Ovambo-Kavango Church (ELOK) in the north, became very strained. The main reason was that the DRC supported apartheid ${ }^{9}$, while ELCSWA and ELOK rejected it completely and supported Swapo ${ }^{10}$. The DRC therefore decided to go it alone, and started intensifying its mission work in the three big northern "homelands". This was the cause of the DRC's urgent intention to plant its own "autonomous" daughter church in the north of Namibia, and thus the direct cause of the constituting of ERCA in 1975.

\section{PREPARATIONS FOR CONSTITUTING THE CHURCH}

Under the leadership of Rev Strauss ${ }^{11}$ the DRC in Namibia started its specific preparations in earnest in 1972. One of the pillars of this initiative was approaching Prof WJ van der Merwe, then Professor of Missiology at the (DRC) Theological Seminary at the University of Stellenbosch, to accept a call to come to Namibia once he retired at Stellenbosch at the end of 1974. Prof van der Merwe accepted the invitation, and spent June-July 1974 at Orumana to teach the evangelist students there, and prepare the way for constituting the church. The author was approached by Rev Strauss, in consultation with Prof van der Merwe, shortly before the conclusion of his theological studies in November 1973 at Stellenbosch to accept a call as missionary to a new "ministry point" ("werkkring" in Afrikaans) at Rundu in January 1974, with the aim of transferring him to the Theological School at Orumana in 1975. At the beginning of 1974 Rev Saayman in Kavango, Rev Paulus in Ovambo, Rev Sarel Visser ${ }^{12}$ at Ohopoho (Kaokoland) and Prof van der Merwe at Orumana (at that stage the four ordained missionary ministers) had to start preparing the way for the constituting synod in July 1975. A preparatory conference of elders of the three congregations had taken place in July 1974 at Orumana. The elders were very ambivalent about the idea of constituting a synod. They wanted to know: did this imply that the

8 It is very difficult to provide accurate statistics for this time in Namibia. The government did not even have accurate statistics for the total population, as there was constant migration to and from Angola. The numbers are based on the author's personal experience as minister of the Takuasa congregation, whose congregants lived on both sides of the Kavango river. I write "homelands" in quotation marks, because the homelands policy was an indigenous South African institution. Yet the policy functioned to all intents and purposes in the north of SWA in terms of the so-called "Odendaal Plan" (cf. Buys \& Nambala 2003:320). This plan was an attempt to implement South African "Bantustan" policies in SWA. As a start, the 3 big northern areas of (from west to east) Kaokoland, Owambo and Kavango, where there had been a minimum of white settlement, were declared as exclusive "Bantu reserves", separated by a so-called "red line" from the rest of SWA. Any workers or visitors to this area needed a police (later an army) permit to enter or leave these areas.

9 For the history to DRC support for apartheid, see Saayman 2007:69-75.

10 Buys \& Nambala (2003:290-330) provide a detailed overview of this quarrel.

11 At the time Rev Strauss was Mission Secretary of the DRC Synod of SWA.

12 Rev Visser accepted a call to become a chaplain in the South African Defence Force (SADF) soon afterwards and took no further part in the process. 
DRC was withdrawing its support? They were also concerned by the fact that the DRC mission had scarcely 1,000 members in total in the three "homelands". How could we consider becoming a credible autonomous church in the midst of a sea of Roman Catholics and a sea of Evangelical Lutherans (in Kavango and Ovambo)? Many of the DRC members had either been born into one of these two churches (especially the Lutheran churches), or still had family connections to them. Starting an autonomous church did not make great sense to them.

In the light of these objections both Prof van der Merwe and the author orally cautioned members of the Mission Commission of the DRC about the advisability of going ahead immediately with constituting the church. Van der Merwe and Saayman added another objection. By that time it was quite clear that SWA would achieve independence at some stage in the foreseeable future. Once that happened, it would make far greater sense to negotiate incorporation back into ELOK. The Triangular Agreement led to the building over many years of very good relationships between the DRC, Rhenish and Finnish missionaries (Buys \& Nambala 2003:362). Many of our own members maintained good relations with the Lutheran congregations, especially in the Kavango. Once a separate church had been constituted, such re-incorporation would become very difficult, if not impossible. For this reason we thought that there was no pressing need to constitute a separate Dutch Reformed church where none had existed before. The DRC "held all the aces", however, as both of us were working as DRC missionaries and were supposed to carry out DRC mission policy, and the total funding for the work (especially also the stipends and salaries of the indigenous evangelists and co-workers) in all three areas came from the "mother church". It was therefore very difficult to withstand DRC pressure that the time had come to institute their "own" daughter church. So despite our personal objections ${ }^{13}$, preparations went ahead. So preparations for the founding synod, to be held at Orumana on invitation of the congregation of Kaokoland (the eldest congregation) from 3-9 July 1975 were carried through. Each congregation would be represented by the missionary minister, the evangelists (unordained but trained co-workers), and a number of elders. The "ministry points" in Caprivi and Bushmanland would be represented by the resident missionary, while the "ministry point" in Walvis Bay would be represented by the evangelist. At that stage of the political history of the mandate territory of South West Africa, the Eastern Caprivi Zipfel was still administered as a separate entity, not integrated into the SWA administration. The position of the San (Bushmen) was still not clear: would they be incorporated into a basically black African synod, or would they get their own church, like the Dutch Reformed Mission Church for Coloured people in SA and the South of SWA ${ }^{14}$ ? The members in Walvis Bay were mainly contract workers in the diamond industry from Kavango and Ovambo, and preferred to be considered as members of their "home" congregations in these two "homelands". In total it meant that the new church would have between 1,000 and 1,500 members only ${ }^{15}$.

13 The question can be asked why we did not arrange for the elders and evangelists to convey their objections personally to the DRC Mission Commission also. In response, I wish to raise two points: In the first place, at that stage of the development of the work the Mission Secretary was the only channel of direct communication with the DRC. Rev Strauss attended the preparatory meeting at Orumana in 1974, and was fully aware of the objections raised in his presence. He brushed the objections aside and argued that constituting an autonomous synod could only be to the advantage of the young church. In the second place, even we as white missionaries had very limited access only to the Mission Commission, where we had no voting rights and could only provide oral advice, which could be accepted or rejected at will by the Commission. None of the indigenous workers at that stage "qualified" in DRC terms to attend Mission Commission meetings.

14 A separate church was eventually constituted in Caprivi, while the San members eventually stayed with the DRC "mother" church - Buys \& Nambala 2003:251-252.

15 I wish to point out again that we had no hard and fast statistics available. In Kaokoland the inhabitants 
In line with DRC church polity at the time, the synod of SWA did not even have to be involved in constituting the new church; it was a function delegated to the Mission Commission (cf Saayman 2008). Rev Strauss (as DRC Mission Secretary) was the office bearer who had the authority to preside over the conventicle; as such a meeting of church councils to constitute a synod is called in Reformed church polity. He had the authority to test and approve the credentials of the delegates from the three congregations. Having done that, the meeting was officially constituted and the election of a moderamen ${ }^{16}$ took place. Rev Saayman was elected moderator, Prof van der Merwe was elected as assessor, and Rev Gerhard Buys (new lecturer at Orumana since April 1975 and delegate of the Kaokoland congregation) was elected as scribe. On taking the chair, Saayman immediately expressed reservations about the fact that only white missionary ministers were elected to the moderamen, but the delegates were adamant that race was not the issue - they chose those who they considered able to carry out their duty ${ }^{17}$ (cf. Strauss 1975:317). Synod then started their official business according to the provisional agenda, which was accepted by synod ${ }^{18}$.

The first issue on the agenda was the name of the new church. There was no disagreement in synod that the name should be Evangelical Reformed Church in Africa (DRC). Tjingaete (1995:22) is mistaken here in his statement that the name was nothing more than "another name for the black DRC [the DRC "daughter church" in SA] in Namibia". The name was proposed by student delegates from Orumana, and was an attempt to give the new church a recognisable identity in the north of Namibia at that time. The use of the word "Evangelical" here therefore has to be understood in the context of a German-speaking colony, where the big denominational differential was between "Katholisch" (Roman Catholic) and "Evangelisch" (Protestant). It had no link whatsoever to the worldwide confrontation of the time between "evangelicals" and "ecumenicals", and was not a word which signified DRC self-understanding. "Reformed" is selfexplanatory - it reflected more than twenty years of mission history. "Africa" was chosen to express the church's self-understanding as an African church, not simply a South African church (Takuasa congregation, for example, had a significant number of members living in Angola). The addition in brackets of DRC was the result of strong pressure by especially the black delegates to verbalise their historical background (in other words, fruit of DRC mission - perhaps to remind the "mother" of this historic link in difficult times in future?). In actual fact this addition soon fell into disuse and the church simply became known as "EGKA" in Afrikaans.

Another very interesting and important decision of synod was the decision by synod that the white missionaries had to become full members of ERCA (cf. Strauss 1975:317) ${ }^{19}$. At that time

were completely nomadic, so it was difficult to know at any given time how many members resided in the congregation. The work in Ovambo was still very new, and there was no reliable church administration system in place yet. In the Kavango our members lived on both sides of the Kavango river (dividing the territories of SWA and Angola), and many of them could no longer participate in a regular manner in congregational activities as a result of the burgeoning "border war".

16 In Reformed polity the moderamen consists of the office bearers of synod duly elected by the approved delegates. In this case a moderator (who also acted as actuary or legal officer), assessor (or vice moderator) and a scribe were elected.

17 The synod consisted of 35 voting delegates; only 4 were white, the other 31 were black. The people elected to the moderamen therefore reflected the preferences of an overwhelming black majority.

18 I am not sure where the official documents and church records can be found at present. At the time they were kept in the offices of the DRC in Windhoek. Since that time the DRC has consolidated its archives in Cape Town, which is where they will possibly be kept now.

19 Here again Tjingaete is mistaken in his assumption that the missionaries led a dualistic existence in both 
the DRC had the policy of allowing dual membership to missionaries working in black daughter churches. Ordained and lay missionaries were allowed to become ex-officio members of the black daughter churches, but retained their membership in white congregations. In case of a doctrinal or ethical trespass committed by the white missionary, the black daughter church could hold a preliminary inquiry, and make recommendations to the white presbytery under whose jurisdiction the missionary resorted. Final judgment could, however, only be delivered by the white presbytery or synod. This was obviously an untenable situation, rooted in racist presuppositions. The ERCA synod (actually the white missionaries working in ERCA) requested that missionaries should become members exclusively of the black daughter church. This request was communicated to the mission commission of the DRC, and the DRC synod of SWA approved this radical change in DRC church polity. So on the first Sunday after the synod all white missionaries with their families transferred their membership to their respective ERCA congregations - a huge step forward and a "first" in the reigning racist configuration of DRC church polity at the time.

Most of the other business of synod had to do with the mundane matters of the everyday running of church business, such as the establishment of ERCA as a "juristic person" in order to have title deeds to its own property, and to establish its relationships to local and national government. The congregations at the "ministry points" in Caprivi and Bushmanland did not join ERCA at this stage, as there were too many uncertainties about the socio-political realities. The newly elected moderamen sought to establish good relationships to ELOK immediately, and in August or September 1975 the moderamen had a meeting with the ELOK church leadership under the legendary Bishop Leonard Auala at the ELOK headquarters in Ovambo. A set of simple rules were adopted unanimously to govern working relationships between the two churches in Kavango and Ovambo, where they were working in the same geographical areas at the time. ELOK asked ERCA to look after the spiritual needs of the ELOK members working in Kaokoland (mainly as nurses and health workers). Soon afterwards, the associate bishop and eventual successor of Auala, Kleopas Dumeni, visited Orumana. He addressed our students and conveyed ELOK's best wishes for the future of the young sister church. This was a big step forward, for in the south of SWA, especially Windhoek, relations between ELOK and the DRC were under severe strain because the DRC was widely regarded as the "Boerekerk" 20 in SWA at the time, ecclesial representative of the hated racist policy of apartheid ${ }^{21}$.

\section{PRELIMINARY CONCLUSIONS}

1. I have elsewhere (Saayman 2007) argued that DRC mission history over more than 350 years can be described as consisting of four distinct waves. ERCA was constituted at the tail end of the third wave, which lasted from 1954-1976 (:69-99). This wave concurred and was indeed inspired by the unfolding "homelands" policy of the apartheid National Party government elected in 1948 (cf Saayman 2008). The blueprint for this development was the Tomlinson Report (Saayman 2007:72-75). The writing was on the wall for this misguided attempt at social engineering on a massive scale with the outbreak of the Soweto uprising on June 16, 1976. The Tomlinson Report's equivalent

the white and the black faith communities (1995:22). They indeed chose explicitly to "live in the world within which ERCA existed".

20 "Boer" (literally: farmer) was the derogatory name applied to all Afrikaners because of their participation in the apartheid government system. The "Boerekerk" was therefore synonomous to "the apartheid church".

21 Buys \& Nambala (2003:290-346) provide a detailed analysis of this history. 
for SWA was the Odendaal Plan (Buys \& Nambala 2003:320). The Odendaal Plan fixed the 3 big northern "homelands" (Kaokoland, Ovambo and Kavango) behind a boundary called "the red line": no white settlement would be allowed there, and the residents needed permits to visit or work in the southern parts of SWA (which they considered as their motherland). The similarities with the apartheid "homelands" policy are clear, and as there was strong correlation between apartheid policy and DRC mission policy (Saayman 2007:69-72), DRC mission policy in SWA closely followed the DRC pattern in SA. To a large extent this explains the urgency in the early 1970s to constitute racially separated churches behind "the red line", in the big northern "homelands", where the majority of the SWA population lived. If one accepts the old (19th and early $20^{\text {th }}$ centuries) distinction between "home mission" and "foreign mission", DRC mission in SWA was somewhat "betwixt and between". It was not truly "home mission", but it was not really "foreign mission" either. The SA government had been administering SWA as a mandated territory first under League of Nations since the end of the First World War, and then under the (disputed) auspices of the UN after the Second World War. There was a strong sentiment among many whites in SA and SWA that the latter should eventually be incorporated into the Union of SA as the fifth province. This feeling grew exponentially after the NP election victory in 1948. Many white South Africans settled in SWA on land provided by the SA government, and SWA received representation in the SA parliament by 6 members. These seats in the SA parliament were always won by the NP, thereby strengthening the NP's hands in carrying out its policies in SA. In a certain sense, therefore, racially separated church formation by the DRC along the lines of the Third Wave of DRC mission history in the north of Namibia was a foregone conclusion.

2. There are observers who object to the formation of ERCA as a "racist institution" (Lombard \& Tjingaete 1995). In 1975 unity between white and black Dutch Reformed churches was not even a point of discussion yet - so there was not the slightest possibility of incorporating ERCA congregations into the white DRC 22 . Unity with the Coloured Dutch Reformed Mission Church at the time was not a practical possibility. The closest DRMC congregation at the time was in Windhoek, more than $500 \mathrm{~km}$ from the southernmost ERCA congregation. There was also the problem of language: the DRMC in SWA at the time was largely an Afrikaans-speaking church, while ERCA used Ovambo, Kavango and Herero languages. Furthermore, I have pointed out above that the DRC considered the creation of an autonomous racially separated church in the "homelands" behind the "red line" as an important politico-theological priority, so they overrode the objections of the missionaries as well as the elders and evangelists. But in a real sense, the tragedy of separation from fellow Christians lay somewhere else. The real tragedy in terms of disunity of churches was, rather, the institutionalisation of the break from the Evangelical Lutheran Churches. The DRC had been working in fraternal fellowship with Lutheran Mission Societies and ELCSA and ELOK for decades in terms of the "Triangular Agreement". Many of the ERCA members, as well as some prominent evangelists had indeed grown up in Lutheran families. The two indigenous Lutheran churches had, though, grown increasingly critical of the imposition of apartheid policies in general and the SA administration in particular during the independence struggle in the 1960s (cf Buys \& Nambala 2003:290-358). This alienated them from the DRC, and

2222 There were white DRC congregations in Kavango and in Ovambo. In Kavango it was a ward of the DRC congregation in Grootfontein, but in Ovambo there were so many civil servants that they had an autonomous congregation in Oshakati. 
therefore there was no way to propagate re-incorporation with ELOK (which was the obvious partner church in cultural and geographical terms). The DRC denomination and its mission in the north actually existed as a Fremdkörper in the body of Christ in the SWA of the middle of the 1960s; far and away the majority of Christians belonged to the Roman Catholic and the Evangelical Lutheran churches. It is for this reason that I regard the final parting of the ways with our historic partners in the north, namely the Evangelical Lutheran churches, as the real tragedy in terms of church disunity.

3. It should be clear from what I have written thus far that the socio-political situation in SWA in the 1960s and 1970s played a very important role in the decision of the DRC to plant an autonomous racially separated DRC denomination in the sensitive northern border areas of SWA at the time ${ }^{23}$. Since 1966 the South African Police had been tasked with containing the SWAPO insurgency, and in 1973-1974 the South African Defence Force (SADF) took over this responsibility. It was very clear that the SA government had chosen the northern border of Namibia with Angola and Zambia (in the Caprivi) as the "South African border" where a "last stand" would be made and insurgents of the liberation movements would be halted in their southward march. In line with the close interrelation between Afrikaner government and Afrikaner church in SA, especially since 1948 (cf Saayman 2007:69-137; Saayman 2008), the SA administration in SWA needed an ecclesiastical partner in the coming struggle, to counter the monopoly influence of the Roman Catholics and Lutherans, who were sympathetic to (and even openly supportive of) SWAPO. In the final analysis this provided the impetus for the urgent desire to institute the ERCA synod ${ }^{24}$. Both Prof van der Merwe and the author regarded the objection discussed in points 3 and 4 as decisive arguments against instituting a new and racially separated church, but their objections were totally overruled by the strong demand generated by the DRC mission history and the sociopolitical circumstances at the time.

4. In a sense the constitution of ERCA with its very good (but very expensive) Theological School at Orumana was doomed to failure, given the fast-changing contextual factors. Orumana was provided with excellent infrastructure, which was very expensive to maintain. Of the three lecturers, which were appointed, Prof van der Merwe had a $\mathrm{Ph}$ D from Yale, and Rev Saayman and Rev Buys had M Th degrees from Stellenbosch (both also obtained their doctorates soon hereafter). The academic and professional level of its staff was therefore far higher than that at, for example, the main Lutheran Seminary, Paulinum. It was completely unthinkable that a small church with less than 2,000, mainly poor, members could afford this luxury. In the beginning all financial support was provided by the DRC in SWA, with occasional calls for financial support being issued to the DRC in $\mathrm{SA}^{25}$. This was to change drastically in the next decade, as the political and military tide turned against South African hegemony in SWA and the south of Angola (cf Lombard \& Tjingaete 1995:24-33). Members of the white DRC were disillusioned because of the overwhelming resistance to continued SA administration among the black population. So civil servants, farmers and business people emigrated, which weakened the financial position of the DRC in SWA itself. The ongoing war

23 I argue the background to this statement fully in Saayman 2008.

24 See the extensive discussion of the "missionary ministry" of the chaplains' services as well as other political interventions of the DRC in Buys \& Nambala 2003:341-346.

25 These appeals often had an openly ideological bias, as in the case of the "Rande vir Rundu" (Rands for Rundu) appeal of the early 1970s which used the Swapo insurgency as motivation to inspire members of the DRC in SA to financially support DRC mission work in Namibia. 
between "white" and "black" also had a deleterious effect on DRC mission enthusiasm both in SA itself and in SWA (cf. Saayman 2007:119-120), which had a shrinking effect on DRC mission involvement in Southern Africa in general. So the availability of the necessary outside financial support to maintain Orumana and the ministry in the three congregations was drastically reduced. Since about 1978 ERCA's existence had become a continual struggle for financial survival. On top of that, Rev Saayman had to leave Orumana at the end of 1978 as a result of ill health, and Prof van der Merwe reached the end of his contract a few months later. This created a serious leadership vacuum in the church itself and also at Orumana. Barely a decade later Orumana was closed, and in the local congregations simple survival was the most urgent priority. It seems to me as if a very clear conclusion can be drawn: instituting a young church with all the accompanying paraphernalia demands big resources and the staying power of an ultra marathon runner. The shifting sands of changing historical and socio-political circumstances do not provide a strong enough foundation to justify over-hasty church planting.

\section{EPILOGUE}

With the benefit of hindsight it is obviously clear that the constituting of the ERCA synod was the last kick of a dying horse: the ebbing of the flow of the extraordinary Third or Tomlinson Wave in DRC mission history. For this reason it will always be (unjustifiably) remembered mainly because it was the last of the Dutch Reformed Church's racially separated daughter churches to be constituted. Obviously there was much more to it than this simple condemnation to the dustbin of history. Some of the indigenous Christians involved were very talented and gifted ${ }^{26}$ people who made a lasting contribution to Namibian national life. The legacy of a racially separated church, daughter of the hated "Boerekerk", remained an albatross around ERCA's neck, though. Today the few survivors are members of the Uniting Reformed Church of SA, playing a very small role in the Reformed family of churches mainly as a result of geographical and linguistic isolation. As a protagonist in the history of those many years ago, I cannot simplistically evaluate this as an insignificant (or "racist") event in Christian history in Southern Africa. Yet I am also very aware of (some of) the mistakes made in the process. So this article is meant as a possible call for further research, which may be useful in the unfolding process of forming non-racial churches in post-apartheid South Africa. There is enough material, as well as fascinating topics, to provide a worthwhile research agenda for other researchers.

\section{BIBLIOGRAPHY}

BUYS GL \& NAMBALA SVV 2003. History of the church in Namibia: an introduction. Windhoek: Gamsberg Macmillan.

Die Sendingblad 9:11, September 1975.

KRITZINGER JJ 1972. Sending en kerk in Suidwes-Afrika, Vol 2. DD Thesis, Univ of Pretoria.

LOMBARD C \& J HUNTER (reds) 1995. Kom ons word een. Namibiese bydraes tot kerkeenwording in die "NGK familie". Windhoek: EIN Publications.

LOMBARD C \& B TJINGAETE 1995. "Wat het met EGKA gebeur?", in Lombard \& Hunter (reds). Kom ons word een.

SAAYMAN W 1979 "Separate Dutch Reformed Churches: notes on the historical perspective”, in Viljoen AC (red) Ekumene onder die suiderkruis.

26 The son (Samuel Mbambo) of one of the elder delegates from Kavango to the constituting synod, $\mathrm{Mr}$ Ndjapau Mbambo, is, for example, today Namibian Ambassador to Russia. 
SAAYMAN W 2007. Being missionary being human: an overview of Dutch Reformed Mission in South Africa. Pietermaritzburg: Cluster Publications.

SAAYMAN W 2008. 'Good mission policy is good state policy in South Africa': the influence of the Tomlinson Report on racial separation in church and state at the dawn of apartheid. Studia Historiae Ecclesiasticae 34(2), 2008, 15-39.

SMITH NJ 1984. Elkeen in sy eie taal. Pretoria: NG Kerk Uitgewers.

STRAUSS P1975. "Die jongste kerk in NG Kerkfamilie", in Die Sendingblad, September 1975, pp.313-317.

VILJOEN AC (red) 1979. Ekumene onder die suiderkruis. Unisa: Pretoria.

\section{KEY WORDS}

Evangelical Reformed Church in Africa (ERCA)

Dutch Reformed Church (DRC)

DRC mission

Kaokoland

Kavango

Ovambo

Racially separated churches

Prof Willem Saayman

Fakulteit Teologie

Universiteit Suid-Afrika

PO Box 392

0003 UNISA

Tel: +27 (0) 124294477

E-mail: saaywil@gmail.com 